\title{
A Comparison of Streptococcal Competence Factors Produced by Strain CHALLIS in Chemically Defined and Complex Media
}

\author{
By J. M. RANHAND, R. M. COLE AND CARMEN G. LEONARD \\ Laboratory of Microbiology, National Institute of Allergy and \\ Infectious Diseases, National Institutes of Health, \\ Bethesda, Maryland 20014, U.S.A. \\ (Accepted for publication II November I970)
}

\begin{abstract}
SUMMARY
A comparison was made between streptococcal competence factors (CF) elaborated by strain CHALLIS in a chemically defined medium and in a complex medium (defined medium containing neopeptone and horse serum). The CF preparations acted similarly in that: (i) both CFs maximally activated the normally non-transformable streptococcal strain wICKY to the competent state when the WICKY cells were incubated for 40 to 100 min. in phase 2; (ii) both CF preparations had to react with wICKY cells for about $20 \mathrm{~min}$. before the cells would take up deoxyribonucleic acid (DNA); (iii) the rates of DNA uptake in WICKY populations were identical when either CF preparation was used; (iv) both CFs activated different concentrations of wICKY cells so that a fixed proportion of the total population transformed to dihydrostreptomycin resistance; and (v) upon dilution both $\mathrm{CF}$ preparations behaved as if they contained more than a single component.

The CF preparations behaved differently in that: (i) WICKY cells activated to the competent state with $\mathrm{CF}$ made in the complex medium generally yielded frequencies of transformation two to eight times higher than $\mathrm{CF}$ prepared in the defined medium, and (ii) $\mathrm{CF}$ prepared in the complex medium occurred in culture filtrates at an apparently higher concentration than CF prepared in the defined medium. This observation may be one reason for the high frequencies of transformation observed with CF made in the complex medium.
\end{abstract}

\section{INTRODUCTION}

Competence is a special physiological state that enables bacterial cells to take up, integrate and express new heritable traits derived from deoxyribonucleic acid (DNA) molecules in solution. The development of competence in some bacteria has been shown to be mediated by extracellular products (Pakula \& Walczak, I963; Tomasz \& Hotchkiss, 1964). In the group $\mathrm{H}$ streptococci one strain, designated as WICKY, can be made competent only when supplied with extracellular factors produced by another strain, CHALLIS (Pakula \& Walczak, 1963). Although the nature of these extracellular factors is unknown, they are heat-labile and destroyed by proteolytic enzymes (Dobrzanski \& Osowiecki, 1967).

Pakula (I965) demonstrated the production of competence factors (CF) by strain CHALLIS in a serum-free complex peptone medium. Leonard, Corley \& Cole (I967) demonstrated the production of CF in a chemically defined medium. Because CF has been routinely prepared in our laboratory in a serum-free synthetic medium over the 
past three years, and because we are trying to identify it chemically, we thought it of interest to compare the action of this CF with one prepared in a complex medium.

A detailed report on the production of $\mathrm{CF}$ in a synthetic medium has been published separately (Leonard, Ranhand \& Cole, 1970).

The kinetic data presented in this report show that CFs prepared in synthetic or complex media act similarly on strain WICKY. However, CF prepared in complex media allows more WICKY cells to develop competence as revealed by their increased frequency of transformation. This difference in CF activities may be quantitative.

\section{METHODS}

Organisms. The organisms used in this study were group $\mathrm{H}$ streptococci strains CHALLIS and WICKY. These strains were originally described by Pakula, Piechowska, Bankowska \& Walczak (1962) and by Pakula \& Walczak (1963).

Growth and maintenance of cultures. CHALLIS cells were grown and maintained in the chemically defined medium (MS6) described by Leonard et al. (I967). WICKY cells were grown and maintained in brain heart infusion (BHI; Difco) containing $2.5 \%$ horse serum (v/v; HS; BBL; Leonard et al. 1967$)$. The HS was heated at $56^{\circ}$ to $60^{\circ}$ for $30 \mathrm{~min}$, before use. Both cultures were stored at $-70^{\circ}$ in their respective media.

Transforming deoxyribonucleic acid (DNA). DNA was isolated from cultures of group H streptococci SBE I 2, which were resistant to more than I mg./ml. dihydrostreptomycin. Cultures grown for $\mathrm{I} 8 \mathrm{~h}$. in a $\mathrm{I}: \mathrm{I}$ mixture of Todd-Hewitt broth (Difco) and trypticase soy broth (BBL) were harvested by centrifugation and lysed with a crude C-I phage enzyme preparation obtained from group C streptococci 26RP 66 (Maxted, I957; Krause, I958; Barkulis, Smith, Boltralik \& Heymann, 1964). DNA was extracted from the cell lysate essentially by the method of Marmur (I96I) with omission of the ribonuclease step. The DNA was stored in $0.85 \% \mathrm{NaCl}$ at $4^{\circ}$. The DNA concentration (determined with diphenylamine; Burton, 1956) used in transformation experiments was in excess and consisted of about $4 \mu \mathrm{g} . / \mathrm{ml}$.

Competence factor production. Competence factor (CF) was obtained from culture filtrates derived from strain cHALLIS grown in a chemically defined medium (MS 6C) described by Leonard et al. (1967). This factor will be designated CF-S.

Competence factor was also prepared from culture filtrates of strain CHALLIS grown in MS 6C supplemented with $2.5 \% \mathrm{HS}(\mathrm{v} / \mathrm{v})$ and I \% neopeptone (Difco; Pakula, I965) and will be designated CF-NS. CF-NS was prepared as follows: CHALLIS cells were grown statically overnight at $37^{\circ}$ in $500 \mathrm{ml}$. of MS 6 and diluted to $10 \%(\mathrm{v} / \mathrm{v})$ in $500 \mathrm{ml}$. of MS $6 \mathrm{C}$ containing $2.5 \% \mathrm{HS}$ and I $\%$ neopeptone. The cells were incubated for $3 \mathrm{~h}$. at $37^{\circ}$, at which time they were centrifuged. The supernatant fluids were decanted and filtered through membranes $(0.45 \mu \mathrm{m}$. pore size; Nalge Co., Rochester, New York), placed in tubes, and frozen in a mixture of dry ice and ethanol.

CF-NS and CF-S lost little, if any, biological activity during 6 months storage at $-20^{\circ}$.

Activation of WICKY cells to the competent state. Five ml. of BHI containing $2.5 \% \mathrm{HS}$ $(\mathrm{v} / \mathrm{v} ; \mathrm{BHI}-\mathrm{HS})$ were added to $0.5 \mathrm{ml}$. of an overnight culture of strain wICKY which had been stored at $-70^{\circ}$. The cells were incubated statically overnight at $37^{\circ}$ (phase $\mathrm{I}$ ). The overnight cell titre was about $3 \times 10^{8}$ colony-forming units $/ \mathrm{ml}$. After overnight growth the cells were harvested by centrifugation and the pellet was resuspended in 
$5 \mathrm{ml}$. of fresh BHI-HS. The resuspended cells were diluted to $5 \%(\mathrm{v} / \mathrm{v})$ in $5 \mathrm{ml}$. BHI-HS (phase 2). Unless specified otherwise, the WICKY cells were incubated in phase-2 for $40 \mathrm{~min}$. at $37^{\circ}$. At the end of phase-2, $0.5 \mathrm{ml}$. of culture was added to $\mathrm{I} .0 \mathrm{ml}$. of $2.5 \% \mathrm{HS}$ containing $0.5 \mathrm{ml}$. of either CF-S or CF-NS. Incubation was continued for $20 \mathrm{~min}$. at $37^{\circ}$ (phase 3 ). DNA was then added ( $0.1 \mathrm{ml}$. of a solution containing $80 \mu \mathrm{g} . / \mathrm{ml}$.) and the cells were incubated an additional $30 \mathrm{~min}$. at $37^{\circ}$ (phase 4). At the end of this period, $0.1 \mathrm{ml}$. of a deoxyribonuclease solution (DNAse; I00 $\mu \mathrm{g}$. $/ \mathrm{ml}$. in $0.02 \mathrm{M}^{-\mathrm{MgSO}_{4}}$; Worthington Biochemical Corp., Freehold, New Jersey) was added for $5 \mathrm{~min}$. (phase 5); the cells were then chilled on ice, diluted appropriately in $0.4 \%$ BHI, and plated in brain heart agar (BHA; phase 6; Difco). Pour plates were used throughout. After $3 \mathrm{~h}$. incubation at $37^{\circ}$ the cells were overlaid with BHA containing $600 \mu \mathrm{g} . / \mathrm{ml}$. dihydrostreptomycin (phase 7). Transformants and colonyforming units were scored after $40 \mathrm{~h}$. incubation at $37^{\circ}$.

All CF-serum mixtures were kept in an ice-water mixture until used. The method above was modified to meet the needs of individual experiments.

\section{RESULTS AND DISCUSSION}

Age of WICKY cells and effect of cell concentration for maximum activation by $C F$. Fig. I $(a)$ and $(b)$ show that wICKY cells must be incubated in phase 2 for at least $40 \mathrm{~min}$. before they can transform maximally with either CF preparation. The maximum percentage transformation ( $\% T=$ number of transformed cells $/ \mathrm{ml} \times$ Ioo divided by the number of colony-forming units $/ \mathrm{ml}$.) obtained was $6 \cdot 7 \%$ with $\mathrm{CF}-\mathrm{NS}$ and $\mathrm{I} \cdot 3 \%$ with CF-S. At zero time (Fig. I $a$ ) the ratio ( $\% T$ observed with CF-NS) to the $\% T$ observed with CF-S) was 13 . By $40 \mathrm{~min}$. the ratio was reduced to almost 6 and remained fairly constant for the duration of the experiment. The significance of this early expression of competence by wICKY cells incubated with CF-NS is not known. It may be a reflexion of the fact that more cells do develop competence with CF-NS.

Fig. I (a) also shows that WICKY cells begin to respond maximally to either CF preparation when they enter early exponential growth as judged by the phase 2 colonyforming unit titres.

During the course of this experiment the phase 2 colony-forming units rose from an initial $3 \times 10^{7} / \mathrm{ml}$. at zero time to $6 \times 10^{7} / \mathrm{ml}$. at $120 \mathrm{~min}$. (Fig. I $a$ ). This rise was compensated for in the experiment so that each tube containing CF received essentially the same number of colony-forming units $\left(9 \times \mathrm{IO}^{6}\right.$ to $\mathrm{I}^{7} 7 \times \mathrm{IO}^{7} / \mathrm{ml}$.; Fig. $\left.\mathrm{I} b\right)$.

Inspection of Fig. I $(a)$ and $(b)$ shows that when cells are added to the CF-serum mixtures at zero time and incubated for $30 \mathrm{~min}$. (phase I to phase 3 ) they are not as competent as their counterparts incubated in BHI-HS for 30 min. (phase 2 to phase 3 ). Although not completely resolved, it appears that any alteration of the medium or cell concentration during phase 2 influences the cells' ability to become maximally competent. Similar results were obtained when the cells and CF preparations were diluted into BHI-HS.

Fig. 2 shows the effect of saturating amounts of CF-S or CF-NS on different population sizes of $40 \mathrm{~min}$. phase 2 wiCKY cells. The data indicate that a constant proportion of cells (slope of I) in each population reacts with $\mathrm{CF}$ and undergoes a genetic transformation. Recently, Tomasz (I970) showed that pneumococcal cultures respond similarly (slope of $\mathrm{r}$ ). The $\% T$ calculated for any point on the curves in Fig. 2 is $4 . \mathrm{I} \%$ 
for CF-NS and $\mathrm{I} \cdot 3 \%$ for CF-S. This constancy in the $\% T$ for each CF preparation may reflect heterogeneity in the WICKY populations as well as in the CF preparations. For example, in any given cell population, a fraction of cells reacts maximally with CF-S. Since CF-NS yields a higher $\% T$, for the same number of cells, we can assume that it contains a factor(s) that is limiting in CF-S.
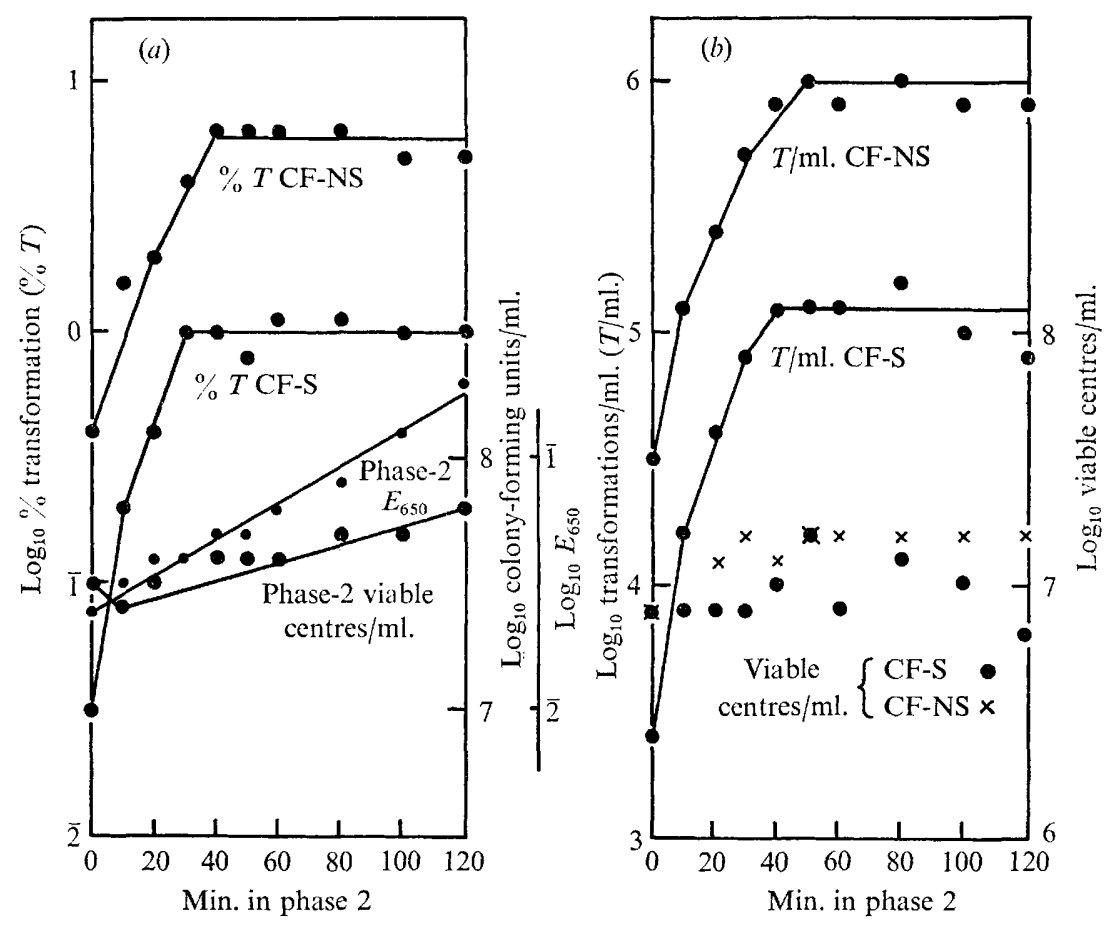

Fig. I. Age of wICky cells for maximum response to CF. An overnight culture of wickY cells $\left(5.0 \mathrm{ml}\right.$.) was centrifuged ( $\left.4800 \mathrm{rev} . / \mathrm{min} ., 20 \mathrm{~min} ., 5^{\circ}\right)$ and the pellet was resuspended in $5.0 \mathrm{ml}$. of BHI-HS. The cells were diluted to $5 \%(\mathrm{v} / \mathrm{v})$ in BHI-HS, and $5.0 \mathrm{ml}$. amounts were added to each of ten test-tubes $\left(16 \times 150 \mathrm{~mm}\right.$.). The cells were incubated at $37^{\circ}$ statically for the indicated time periods (phase 2). At each time period an appropriate volume of cells $(0.5 \mathrm{ml}$. at zero-time, and $0.15 \mathrm{ml}$. at I $20 \mathrm{~min}$.) was added to $1.0 \mathrm{ml} .2 .5 \% \mathrm{HS}(\mathrm{v} / \mathrm{v})$ containing either $0.5 \mathrm{ml}$. CF-S or CF-NS. When required, volumes were adjusted to $2.0 \mathrm{ml}$. with BHI-HS. The cells plus CF were incubated $20 \mathrm{~min}$. at $37^{\circ}$ and $0.1 \mathrm{ml}$. of a DNA solution $\left(80 \mu \mathrm{g} . / \mathrm{ml}\right.$.) was added for $30 \mathrm{~min}$. DNAse $\left(0 . \mathrm{I} \mathrm{ml}\right.$. of $100 \mu \mathrm{g} . / \mathrm{ml}$. in $\left.0.02 \mathrm{M}-\mathrm{MgSO}_{4}\right)$ was then added for $5 \mathrm{~min}$. The cells were chilled on ice, diluted appropriately and plated in BHA. After $3 \mathrm{~h}$. at $37^{\circ}$ the cells were overlaid with BHA containing $600 \mu \mathrm{g} . / \mathrm{ml}$. dihydrostreptomycin. Extinction $(E)$ was measured at $650 \mathrm{~nm}$. in a $\mathrm{I} \mathrm{cm}$. cuvette in a Beckman DU spectrophotometer. $\% T=$ no. of transformations $/ \mathrm{ml} . \times 100$ divided by no. of colonyforming units $/ \mathrm{ml}$. CF-NS = competence factor from a serum and neopeptone containing medium. $\mathrm{CF}-\mathrm{S}=$ competence factor from a synthetic medium.

Kinetics of DNA uptake by WICKY cells incubated with $C F-S$ or $C F-N S$. Fig. 3(a) shows the kinetics of DNA uptake by wICKY cells which were pre-incubated with CF-S or CF-NS for $20 \mathrm{~min}$. prior to the addition of DNA. DNA was taken up in an irreversible manner (resistant to DNAse) almost immediately, and the $\% T$ reached a maximum value at about $30 \mathrm{~min}$. The rates of DNA uptake by WICKY cells treated with either CF-S or CF-NS were essentially the same. 
Fig. $3(b)$ shows that cells must be incubated with either CF-S or CF-NS for a minimum time of about $20 \mathrm{~min}$. before DNA is taken up in an irreversible fashion. Once more, the observed rates of DNA uptake with either CF are essentially the same. Pakula \& Walczak (1963) reported a similar incubation period with strain CHALLIS. In the reaction between pneumococci and its CF, no lag period is observed (Tomasz, 1970).

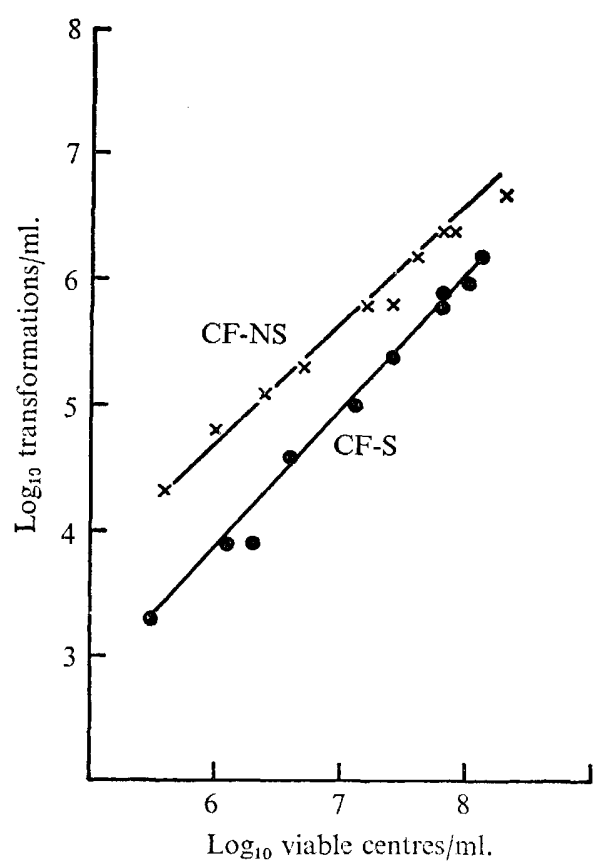

Fig. 2. Effect of saturating concentrations of $\mathrm{CF}-\mathrm{S}$ or $\mathrm{CF}-\mathrm{NS}$ on different population sizes of 40 min. phase 2 wICKY cells. WICKY cells were grown overnight in BHI-HS and diluted to $5 \%(\mathrm{v} / \mathrm{v})$ in $40 \mathrm{ml}$. BHI-HS. The cells were incubated $40 \mathrm{~min}$. and centrifuged (Io min., $\left.4800 \mathrm{rev} . / \mathrm{min} ., 5^{\circ}\right)$. The pellet was resuspended in $4.0 \mathrm{ml}$. BHI-HS and different volumes of cells $(0.01$ to $0.5 \mathrm{ml}$.) were added to $\mathrm{I} .0 \mathrm{ml} .2 .5 \% \mathrm{HS}(\mathrm{v} / \mathrm{v})$ containing either $0.5 \mathrm{ml}$. CF-S or CF-NS. Volumes were adjusted to $2.0 \mathrm{ml}$. with BHI-HS. After $20 \mathrm{~min}$. at $37^{\circ}$, DNA was added for $30 \mathrm{~min}$. followed by DNAse for $5 \mathrm{~min}$. The cells were then treated as described in Methods.

Effect of CF concentration on the activation of WICKY cells. In general, WICKY cells treated with CF-NS always yielded higher percentages of transformation when compared to cells treated with CF-S. It was of interest, therefore, to determine how much more CF activity was present in the former preparation. CF-S and CF-NS were serially diluted by twofold steps in $2.5 \% \mathrm{HS}(\mathrm{v} / \mathrm{v} ;$ Fig. 4) and assayed with $40 \mathrm{~min}$. phase-2 wickY cells. These curves show that CF-NS can be diluted further than CF-S and still yield high percentages of transformation: a I/256 dilution of CF-NS yielded $\mathrm{I} \cdot \mathrm{I} \%$ transformation whereas the same dilution of $\mathrm{CF}-\mathrm{S}$ was essentially inactive. The slopes of these experimental lines (determined between the arrows) are $\mathrm{I} \cdot 7$ for CF-NS and $3 \cdot 0$ for CF-S. In other experiments, slopes of $I \cdot 2$ to $I \cdot 5$ were obtained with CF-NS, and slopes of 3 to 4 were obtained with CF-S. Pakula (1965) reported a similar observation (slope of 3 ) using CF prepared in complex peptone media, and, 
more recently, Tomasz (I970) observed the same phenomenon (slope of 3 to 3.5 ) with pneumococci. The data presented in Fig. 4 are taken to mean (i) that CF prepared in a synthetic medium or in a complex medium consists of several components, or (ii) that dilution of $\mathrm{CF}$ destroys its activity. Assuming that there is no loss in activity due to dilution per se, these data indicate that CF-S and CF-NS consist of two to four components and that CF-NS has these components in excess. This may explain the heterogeneity observed in Fig. 2 and may also explain why CF has been difficult to

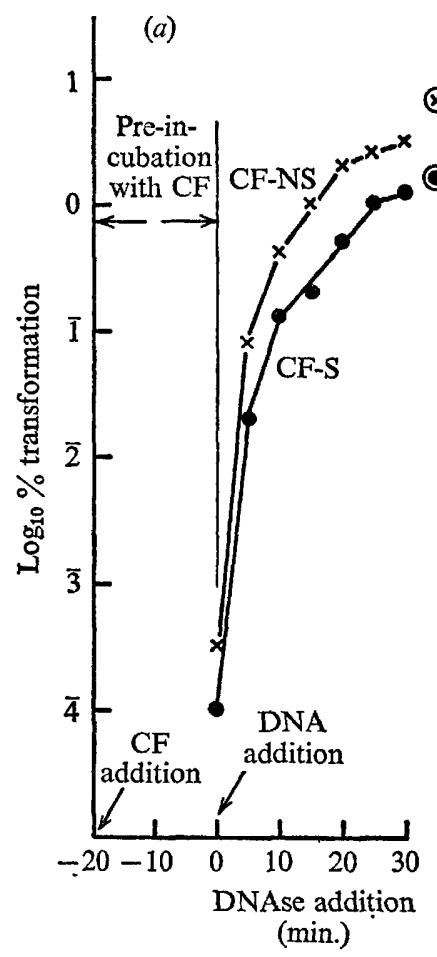

(b)

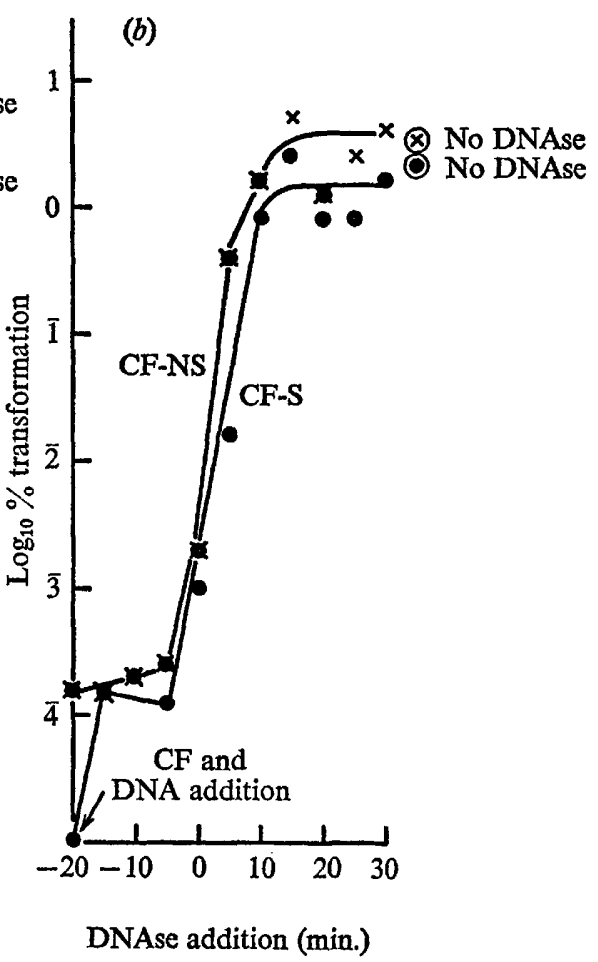

Fig. 3(a). Kinetics of DNA uptake by wickY cells pre-incubated with CF. Five ml. of WICKY cells were grown overnight in BHI-HS and centrifuged $\left(4800 \mathrm{rev} . / \mathrm{min} ., 5^{\circ}\right)$. The pellet was resuspended in $5.0 \mathrm{ml}$. BHI-HS and the cells were diluted to $5 \%(\mathrm{v} / \mathrm{v})$ in BHI-HS. The diluted cells were incubated $40 \mathrm{~min}$. at $37^{\circ}$ (phase 2), at which time $0.5 \mathrm{ml}$. was added to $\mathrm{I} \cdot 0 \mathrm{ml} .2 .5 \% \mathrm{HS}(\mathrm{v} / \mathrm{v})$ containing $0.5 \mathrm{ml}$. CF-S or CF-NS (phase 3 ). Incubation was continued for $20 \mathrm{~min}$., at which time $0.1 \mathrm{ml}$. of a DNA solution $(80 \mu \mathrm{g} . / \mathrm{ml}$.) was added to each tube. DNAse $\left(0 . \mathrm{I} \mathrm{ml}\right.$. of $100 \mu \mathrm{g} . / \mathrm{ml}$. in $\left.0.02 \mathrm{M}-\mathrm{MgSO}_{4}\right)$ was then added at the indicated time periods. At $35 \mathrm{~min}$. all cells were chilled on ice, diluted appropriately, and plated in BHA. The remainder of the protocol is described in Methods.

Fig. $3(b)$. Kinetics of DNA uptake by wICKY cells pre-incubated with CF and DNA. The above protocol was followed except CF and DNA were added simultaneously to WICKY cells at zero time in phase 3 . DNAse was added at $5 \mathrm{~min}$. intervals starting at zero time ( -20 min.).

purify. Ion-exchange chromatography of CF-S also suggests that more than one component is present since we obtained two to three active fractions (unpublished results). However, we did not observe synergism or additivity between them.

The data in Fig. 4 may also be interpreted to mean that CF contains a single molecular species and that the number of CF molecules that reach any one cell is important 
for the development of competence. Obviously, this will be resolved only when each CF preparation is purified.

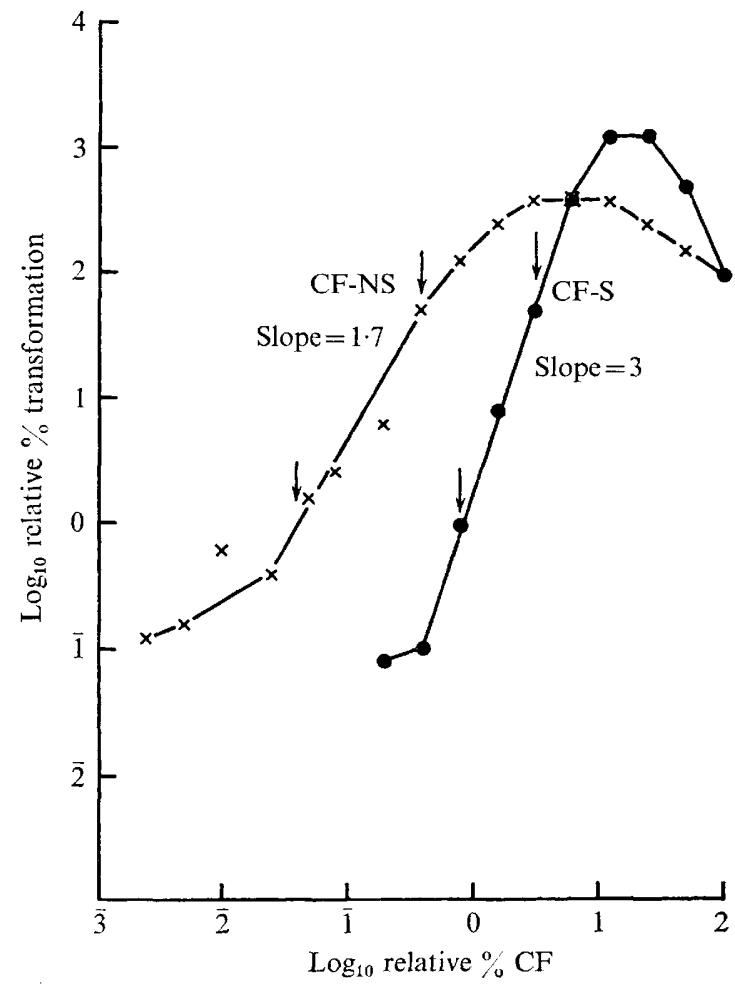

Fig. 4. Effect of CF concentration on the activation of wiCKY cells. CF-S and CF-NS were serially diluted in $2.5 \% \mathrm{HS} \mathrm{(v/v)} \mathrm{by} \mathrm{twofold} \mathrm{steps.} \mathrm{Tube} \mathrm{no.} 2$ received $\mathrm{I} \cdot 5 \mathrm{ml}$. CF and $\mathrm{I} \cdot 5 \mathrm{ml}$. $2.5 \% \mathrm{HS}(\mathrm{v} / \mathrm{v})$. This was mixed and $\mathrm{r} .5 \mathrm{ml}$. was transferred to the next tube containing $\mathrm{I} .5 \mathrm{ml} .2 .5 \% \mathrm{HS}(\mathrm{v} / \mathrm{v})$. The procedure was repeated until all dilutions were made. WICKY cells $(0.5 \mathrm{ml} ., 40 \mathrm{~min}$. phase 2 cells) were then added for $20 \mathrm{~min}$., at which time $0.1 \mathrm{ml}$. of a DNA solution ( $80 \mu \mathrm{g}$. $/ \mathrm{ml}$.) was added for $30 \mathrm{~min}$. DNAse was then added $(0.1 \mathrm{ml}$., $100 \mu \mathrm{g}$. $/ \mathrm{ml}$. in $0.02 \mathrm{M}-\mathrm{MgSO}_{4}$ ) for $5 \mathrm{~min}$. The remainder of the protocol is as described in Methods. The relative percentage $\mathrm{CF}$ in each tube corresponds to tube no. $\mathrm{I}$, having $\mathrm{I} 00 \% \mathrm{CF}(\mathrm{I} \cdot 5 \mathrm{ml}$. of undiluted CF). For CF-S, $0.38 \%$ transformation was adjusted to $100 \%$; for CF-NS, $2.0 \%$ transformation was adjusted to $100 \%$.

This work was initiated during the tenure of a Postdoctoral Research Fellowship awarded to J.M.R.

We acknowledge the technical assistance of Mr J. Cunningham.

\section{REFERENCES}

Barkulis, S. S., Smith, C., Boltralik, J. J. \& Heymann, H. (1964). Structure of streptococcal cell walls. IV. Purification and properties of streptococcal phage muralysin. Journal of Biological Chemistry 239, 4027-4033.

Burton, K. (1956). A study of the condition and mechanism of diphenylamine reaction for the colorimetric estimation of deoxyribonucleic acid. Biochemical Journal 62, 31 5-323.

DOBRZANSKI, W. T. \& OSOWIECKI, H. (1967). Isolation and some properties of the competence factor from group H Streptococcus strain CHALlis. Journal of General Microbiology 48, 299-304. 
KraUSE, R. M. (1958). Studies on bacteriophages of hemolytic streptococci. II. Antigens released from the streptoccocal cell wall by a phage-associated lysin. Journal of Experimental Medicine I08, 803-821.

Leonard, C. G., Corley, D. \& Cole, R. M. (I967). Transformation of streptococci in chemically defined media. Biochemical and Biophysical Research Communications 26, I8I-I86.

Leonard, C. G., Ranhand, J. M. \& Cole, R. M. (1970). Competence factor production in chemically defined media by non-competent cells of group $\mathbf{H}$ Streptococcus strain chaLLIs. Journal of Bacteriology 104, 674-683.

MARMUR, J. (1961). A procedure for the isolation of deoxyribonucleic acid from micro-organisms. Journal of Molecular Biology 3, 208-218.

MAXTED, W. R. (1957). The active agent in nascent phage lysis of streptococci. Journal of General Microbiology $16,584-595$.

PakUla, R. (1965). Production of competence-provoking factor and development of competence of a transformable Streptococcus in serum-free media. Canadian Journal of Microbiology Ir, 81 I822.

Pakula, R., Piechowska, M., Bankowska, E. \& Walczak, W. (1962). A characteristic of DNA mediated transformation systems to two streptococcal strains. Acta microbiologica polonica II, 205-222.

Pakula, R. \& Walczak, W. (1963). On the nature of competence of transformable streptococci. Journal of General Microbiology 31, I25-I 33.

Tomasz, A. (1970). Cellular metabolism in genetic transformation of pneumococci: requirement for protein synthesis during induction of competence. Journal of Bacteriology Ior, 860-87I.

Tomasz, A. \& Hoтchкiss, R. D. (1964). Regulation of the transformability of pneumococcal cultures by macromolecular cell products. Proceedings of the National Academy of Sciences of the United States of America 5r, 480-487. 